\title{
SUVREMENI KNJIŽNIČNI PROSTORI - OD IDEJE DO REALIZACIJE ZGRADE GRADSKE KNJIŽNICE U KARLOVCU
}

\author{
CONTEMPORARY LIBRARY SPACES - \\ FROM THE IDEA TO REALISATION OF THE CITY \\ LIBRARY BUILDING IN KARLOVAC
}

\begin{abstract}
Frida Bišćan
Nacionalna i sveučilišna knjižnica u Zagrebu

fbiscan@nsk.hr
\end{abstract}

UDK / UDC [022:727]:027.3(497.5 Karlovac)

Izvorni znanstveni rad / Original scientific paper

Prihvaćeno / Accepted: 11.5.2017.

\section{Sažetak:}

Prostori knjižnica uvijek su bili rezultat vremena, potreba, mogućnosti i promišljanja tadašnjih knjižničara, arhitekata, kao i zajednice kojoj su knjižnične usluge namijenjene. Narodne knjižnice po svom su određenju definirane kao javne ustanove, što označava njihovu otvorenost javnosti, „služenje“ javnosti; djelatnost im je usmjerena na zadovoljavanje kulturnih i obrazovnih potreba lokalne zajednice. Suvremeno doba, doba novih usluga i informacijskih tehnologija, traži novi pristup ne samo korisnicima nego i prostorima u kojima oni borave.

U uvodnom ću dijelu na primjeru karlovačke knjižnice izložiti razvoj ideje o izgradnji funkcionalne i estetski privlačne zgrade narodne knjižnice u Karlovcu. Rad je nastao sadržajnom analizom arhivskih dokumenata, važećih zakonskih propisa i dostupne stručne literature o planiranju prostora narodnih knjižnica.

U radu će biti govora o nedostatku knjižničnog prostora tijekom godina, promišljanjima o novim prostorima i javnom zagovaranju koje je provođeno u određenim razdobljima kako bi se taj problem riješio. Rješenje prostora karlovačke knjižnice bit

Vjesnik bibliotekara Hrvatske 60, 2-3(2017), 175-191

ISSN 0507-1925

(C) VBH 2017. 
će obrazloženo po etapama kroz koje je prolazilo. Ujedno će se kroz prostore i njihov sadržaj usporediti potrebe korisnika nekada i danas u suvremenom društvu.

Ključne riječi: narodne knjižnice, knjižnični prostor, korisnici, knjižničari, javno zagovaranje, Karlovac, Gradska knjižnica „Ivan Goran Kovačić“ Karlovac

\section{Summary}

Library spaces have always been the result of the amount of invested time, needs, possibilities, and reflections of the librarians in a certain period, the architects, and the general community to which the library services were intended. Public libraries are defined as public institutions, which means that they are open to the public, serve the public, and their activities are directed towards satisfying the cultural and educational needs of the local communities. The modern era, the age of new services and information technologies, requires a new approach, not only to the users, but also to the spaces they use during their visits to libraries.

In the introductory part of the paper, based on the example of the City Library „Ivan Goran Kovačić" in Karlovac, the author presents the idea of constructing a functional and aesthetically pleasing public library building in Karlovac. The paper is based on the content analysis of archive documents, applicable legal regulations, and the available professional literature on public libraries planning.

The paper analyses the lack of library space in the Karlovac Library over the years, planning new spaces, and public advocacy that has been carried out over a period of time in order to resolve this problem. The solution of the Karlovac library space is explained by commenting the stages it went through over the years. At the same time, through the analysis of the aspects of the library spaces and equipment, the needs of the users in the past and today, in the modern society, are compared.

Keywords: public libraries, library space, users, librarians, public advocacy, Karlovac, City Library „Ivan Goran Kovačićc“ Karlovac

\section{Uvod}

Narodne knjižnice po svom su određenju definirane kao javne ustanove, što označava njihovu otvorenost javnosti, ,služenje“ javnosti; djelatnost im je usmjerena na zadovoljavanje kulturnih i obrazovnih potreba lokalne zajednice. Osnovno im je načelo dostupnost službi i usluga svim pojedincima u zajednici. One su javni prostor kulture, obrazovanja i informiranja, kulturno i intelektualno središte zajednice koje osigurava znanje, informacije i osobni razvoj kroz komunikaciju koju gradi na sudjelovanju građana u oblikovanju kulturnog sadržaja, čime prido- 
nosi razvoju zajednice te osnažuje izgradnju društvenih mreža. Korištenjem novih informacijskih i komunikacijskih tehnologija narodne knjižnice omogućavaju pristup svim vrstama informacija i stvaraju nove sadržaje koji mogu zadovoljiti potrebe svih korisnika. Vrijednost narodnih knjižnica u lokalnoj zajednici utvrđuje se na osnovi pokazatelja uspješnosti, a to su građa i usluge koje nude kako bi zadovoljili potrebe korisnika (identificiranje potencijalnih korisnika, analiza njihovih potreba), organizacija službi i usluga za korisnike, edukacija korisnika, izgradnja zbirki, prostorno planiranje, educirano osoblje i kvalitetno upravljanje. ${ }^{1}$

Važnu ulogu u radu narodne knjižnice imaju knjižnične zgrade, prostor predviđen za korisnike i knjižničare koji svojim vanjskim i unutrašnjim dizajnom u današnje vrijeme trebaju zadovoljiti potrebe korisnika 21. stoljeća. Bez obzira na to radi li se o izgradnji nove zgrade knjižnice ili o prenamjeni prostora, knjižnični prostor mora zadovoljavati uvjete određene Standardima za narodne knjižnice, poštujući pritom IFLA-in i UNESCO-ov Manifest za narodne knjižnice, IFLAine Smjernice za narodne knjižnice i IFLA-ine Smjernice za knjižnične zgrade.

Poželjno je da zgrada knjižnice bude u centru grada ili na mjestu gdje se odvijaju različite aktivnosti kako bi bila što dostupnija svim stanovnicima zajednice, ako je moguće, s osiguranim parkirališnim prostorom. Suvremena knjižnica mora biti funkcionalna, veličine koja će zadovoljiti potrebe fonda, knjižničara, korisnika i kompletne lokalne zajednice, s odjelima namijenjenim svim korisničkim skupinama. Uređenje prostora uvjetovano je nizom elemenata, od dobre osvijetljenosti, jasno vidljivih oznaka, prostora za sve zbirke, adekvatnog namještaja i prostora za tihi rad do pristupačnosti za sve korisnike, osobito vodeći računa o osobama s posebnim potrebama. ${ }^{2}$

IFLA-ina Sekcija za narodne knjižnice objavila je 2009. godine nove preporuke koje su dopuna Manifestu o prilagođavanju svojih usluga novim tehnologijama 21. stoljeća. Dio uputa odnosi se i na knjižnične zgrade: „Zgrade narodnih knjižnica proširiti u prostor zajednice i kulturni prostor, a ne samo fizičko mjesto skladištenja znanja.“3 Pojednostavljeno rečeno, potrebna je otvorenost prostora zgrada/prostor sa što manje zatvorenih spremišta kako bi većina prostora i građe bila dostupna korisnicima. Uz to treba voditi računa o funkcionalnosti opreme koja mora biti prilagođena fondu, knjižničarima i korisnicima. Važan je segment

1 IFLA-ine smjernice za narodne knjižnice / uredile Christie Koontz i Barbara Gubbin ; [s engleskog prevela Irena Kranjec]. 2. hrvatsko izd. (prema 2. izmijenjenom izd. izvornika). Zagreb : Hrvatsko knjižničarsko društvo, 2011. Str. 22-27.

2 Faulkner-Brown, Harry. Some thoughts on the design of major library buildings. // Intelligent Library Buildings : Proceedings of the 10th Seminar of IFLA's Library Buildings and Equipment Section. The Hague, Netherlands, 1997. Str. 14-26. [citirano: 2017-04-20]. Dostupno na https:// www.ifla.org/publications/intelligent-library-buildings.

3 IFLA-ine smjernice za narodne knjižnice. Nav. dj., str. 118-119. 
uređenja jednostavnost grafičkog dizajna koji će prostor učiniti toplim i bliskim svakom korisniku i posjetitelju knjižnice.

Prvi korak u planiranju jest istraživanje koje će dati jasnu viziju nove zgrade, a koja će u potpunosti biti u službi korisnika i knjižničara, tj. cijele zajednice. Osim konzultiranja dostupne literature, poželjno je posjetiti i razgledati nove knjižnične zgrade kako bi se na ostvarenim projektima učilo te kako bi se s viđenim usporedile vlastite potrebe. Istraživanje treba uključiti mišljenje zajednice, osoblja knjižnice, osnivača i ostalih sudionika koji na bilo koji način svojim idejama mogu pomoći u pronalaženju najboljeg rješenja. Pritom treba voditi računa o broju stanovnika, potrebama zajednice, građi/zbirkama koje knjižnica posjeduje, mogućnosti prilagodbe promjenama u društvu, dobroj komunikaciji s osnivačima te interesima osnivača i ostalih potencijalnih financijera. ${ }^{4}$

Suvremeni knjižnični prostor podliježe kulturnim i socijalnim transformacijama u društvu i novim potrebama koje donosi društvo znanja. Andrew McDonald navodi deset kvaliteta za dobar knjižnični prostor: funkcionalan, prilagodljiv, dostupan, raznolik, interaktivan, vodljiv, ekološki prikladan, siguran, efikasan i prikladan za informacijsku tehnologiju. ${ }^{5}$ Potrebno je razmišljati o prostoru koji će služiti zajednici kroz sljedećih nekoliko desetljeća, što podrazumijeva procjenu veličine fonda i različitih zbirki, broja korisnika, događanja i tehničke opreme, a o čemu ovisi planiranje veličine prostora.

Izrada programske osnove za izgradnju nove zgrade (ili preuređenje postojećeg objekta) zahtjevan je i opsežan posao koji uključuje tim iskusnih knjižničnih djelatnika. Potrebno je utvrditi lokaciju, ciljeve i zadaće, misiju i viziju knjižnice kao kulturnog, obrazovnog, informacijskog i kulturnog središta zajednice, odrediti ciljne skupine i osmisliti strateški plan razvoja knjižnične djelatnosti u sljedećem razdoblju. To uključuje ulogu knjižnice u lokalnoj, regionalnoj i nacionalnoj knjižničnoj mreži. Ovisno o vrsti knjižnice i njezinoj ulozi u knjižničnom sustavu, uzimajući u obzir statističke podatke i pokazatelje potreba lokalne zajednice, valja prijeći na izračun potrebne kvadrature objekta koji, osim procjene porasta broja stanovnika u narednih tridesetak godina, treba sadržavati i procjenu porasta fonda i korisnika. Na temelju definiranih parametara valja prijeći na planiranje zgrade koje uključuje područje gradnje, vanjski izgled zgrade i unutrašnji raspored prostora sa svim popratnim sadržajima. Planiranje treba uključiti i okvirnu financijsku konstrukciju cjelokupnog projekta, uključujući i troškove održavanja. ${ }^{6}$

\footnotetext{
4 Key issues in building design. [citirano: 2016-02-17]. Dostupno na http://www.ifla.org/files/ assets/library-buildings-and-equipment/Publications/key-issues-in-building-design-en.pdf.

5 IFLA Library building guidelines: developments and reflections. Muenchen, K. G. Saur, 2007. Str. 13-26.

6 Novljan, Silva. Načrtovanje prostora za knjižnično dejavnost v lokalni skupnosti. // Načrtovanje gradnje in opreme knjižnic / Silva Novljan, Robert Potokar, Rajko Slokar. Ljubljana : Narodna in univerzitetna knjižnica, 2001. Str. 57-70.
} 
Nakon što je programska osnova prihvaćena i odobrena, raspisuje se natječaj za izradu idejnog projekta nove zgrade (ili preuređenje postojeće).

Nakon odabira, u narednom je razdoblju od izuzetne važnosti dobra komunikacija i razumijevanje između knjižničara i arhitekata kako bi zdanje u svojoj konačnici zadovoljilo potrebe za koje je namijenjeno, ali da istovremeno čini savršen spoj obiju struka, tj. arhitekture, knjižničarskih zahtjeva i potreba zajednice.

\section{Planiranje zgrade Gradske knjižnice „Ivan Goran Kovačićc6}

S namjerom da riješi pitanje društvenih prostorija, Ravnateljstvo Društva narodne čitaonice osniva krajem 1962. godine privremeni Odbor (Odbor narodne karlovačke čitaonice) koji početkom siječnja 1863. izdaje sljedeći Proglas:

„Iz rodoljubivih srcah potekla je vrlo sretna misao da se u bijelomu gradu Karlovcu sagradi zdanje čitaoničko putem dionicah. Ovo je tim nuždnija stvar što Karlovac ide na susret velikoj skoroj budućnosti, a ne bi po njega dostojno bilo da bude nepripravan zatečen." 7

Ovaj ulomak početak je Proglasa karlovačkih rodoljuba kojim pozivaju svoje sugrađane na upis dionica za gradnju „Građanskog doma“. Članovi Društva svjesni su da ubrzani gospodarski razvoj utječe na društveni, politički i kulturni život, a čitaonica svojim radom pridonosi kulturnom napretku i pismenosti naroda. Proglasom je ukazano na potrebu izgradnje zgrade koja bi služila za potrebe čitaonice, ali i ostalih kulturnih ustanova u gradu, a upisom dionica osigurala bi se za to potrebna sredstva. Tekst Proglasa navodi i lokaciju gdje bi „zdanje čitaoničko" trebalo biti. Članovi Odbora izražavaju uvjerenje kako se Karlovčani, poznati po svom domoljublju, neće oglušiti na taj poziv. Fascinantan je podatak o svijesti ljudi druge polovice 19. stoljeća o ulozi knjižnice u društvu i njezinim potrebama. Nažalost, ta ideja tada nije zaživjela, ali je dobila svoj sretan epilog stoljeće kasnije, kada je izgrađena prva namjenski projektirana narodna knjižnica u Hrvatskoj.

Problem prostora stalno je prisutan, od osnivanja Ilirskog čitanja društva 1838. godine do 70 -ih godina 20 . stoljeća. ${ }^{8}$ Nakon niza preseljenja iz jednog prostora u drugi i otvaranja odjela na dislociranim lokacijama, postalo je jasno kako bez izgradnje nove zgrade koja bi osigurala dostatan prostor (za korisnike i knjižni-

\footnotetext{
7 Mikulić, Rosana. Ilirskoga čitanja društvo / Društvo narodne čitaonice. // Gradska knjižnica „Ivan Goran Kovačić“ - Karlovac : 1838.-2008. : prilozi za povjesnicu / urednica Frida Bišćan. Karlovac : Gradska knjižnica „Ivan Goran Kovačić“, 2008. Str. 36 i 63.

8 Bišćan, Frida. Karlovačka knjižnica: nova vizura grada. // Narodne knjižnice za sadašnjost i budućnost : koncepti, arhitektura, tehnologija : zbornik radova / 5 . savjetovanje za narodne knjižnice u Republici Hrvatskoj, Lovran, 3.-6. listopada 2007. ; [urednica Ljiljana Črnjar ; prijevodi tekstova sa slovenskog i engleskog Andreja Silić Švonja]. Str. 31-34.
} 
čare, uključujući i spremište), a čime bi se omogućilo učinkovito funkcioniranje knjižnice sa svim njezinim ciljevima i zadaćama, nema kvalitetnog i dugoročnog rješenja.

Zato početkom 1970. godine započinje sustavno zagovaranje izgradnje nove zgrade za potrebe knjižnice. Na temelju redovnog godišnjeg izvješća o radu i poslovanju karlovačke knjižnice za 1969. godinu, u kojem je ponovno naglašen sada već dugogodišnji problem prostora, ravnatelj Ivan Jurković sastavlja dopis Skupštini općine Karlovac u kojem daje pregled povijesti Gradske knjižnice i njezina značaja u društvu za kulturu i obrazovanje svih slojeva uže i šire zajednice, čime obrazlaže potrebu za većim prostorom za rad knjižnice i traži suglasnost Općine za izgradnju nove zgrade knjižnice. Nakon načelne suglasnosti Općine, Jurković se obraća Nacionalnoj i sveučilišnoj biblioteci u Zagrebu kao matičnoj knjižnici za pomoć pri izradi programske osnove za izgradnju nove zgrade knjižnice. Senzibiliziranje javnosti za projekt bilo je od izuzetne važnosti, u čemu su veliku ulogu imali lokalni mediji. ${ }^{9}$

Građevni program za novu zgradu Gradske biblioteke „Ivan Goran Kovačić“ u Karlovcu izradio je 1970. Matko Rojnić ${ }^{10}$, tadašnji ravnatelj NSK, koji je već imao bogato iskustvo na tom području jer je radio na izradi koncepcije i programa za novu zgradu Nacionalne i sveučilišne knjižnice. Njegov stručni i znanstveni rad, poznavanje svih segmenata knjižničarske struke, uključujući i poznavanje zgrada, tj. prostora knjižnice i njegove funkcionalne povezanosti, bile su jamstvo da će knjižnica dobiti kvalitetan i na visokoj stručnoj razini izrađen građevni program. ${ }^{11}$ Građevni program sastoji se od nekoliko poglavlja. Osim uvodnog dijela, navedeni su elementi koje treba uzeti u obzir pri izradi nacrta za zgradu knjižnice, a to su ,zadaci biblioteke, namjena biblioteke, fond biblioteke, porast fonda biblioteke, broj čitača i predvidivi porast čitača, poslovi i službe u biblioteci, broj radnika biblioteke i prostor". Svako poglavlje detaljno je razrađeno. ${ }^{12}$ Rasprava o izrađenom Građevnom programu vođena je u Karlovcu, a konzultirane su i knjižnice u Zagrebu (Gradska knjižnica, Knjižnica „Bogdan Ogrizović“ i Knjižnica „Vladimir Nazor") i Gradska knjižnica u Rijeci. Građevni program za novu zgra-

\footnotetext{
9 Glodić, Bogdan. Nova kuća za čitaoce. // Karlovački tjednik 18, 47/48 (1970), str 12.

10 Rojnić, Matko. Gradska biblioteka „Ivan Goran Kovačić“ u Karlovcu : građevni program. Zagreb, 1970.

11 Stipanov, Josip. Matko Rojnić - pokretač i obnovitelj hrvatskog knjižničarstva. // Stručni skup Matko Rojnić: knjižničar i povjesničar povodom 100. obljetnice rođenja (1908.-1981.), Medulin, 12. svibnja 2008. : zbornik radova / uredili Bruno Dobrić i Slavko Harni. Zagreb : Hrvatsko knjižničarsko društvo : Nacionalna i sveučilišna knjižnica ; Pula : Gradska knjižnica i čitaonica, 2010. Str. 22-41.

12 Rojnić, Matko. Gradska biblioteka „Ivan Goran Kovačić“ u Karlovcu : građevni program. Zagreb, 1970.
} 
du karlovačke knjižnice razmatran je i na sjednici Savjeta za biblioteke Hrvatske 24. 11. 1970., gdje je u potpunosti prihvaćen. ${ }^{13}$

U prosincu 1970. godine ravnatelj Ivan Jurković podnosi zahtjev Općinskom zavodu za komunalne poslove i urbanizam u kojem traži, na temelju već dostavljenog Građevnog programa, određivanje lokacije za izgradnju nove zgrade knjižnice, naglašavajući elemente o kojima treba voditi računa pri određivanju lokacije i navodeći tri prijedloga mjesta za izgradnju. ${ }^{14}$ Rješenje o uvjetima građenja, na temelju detaljnog urbanističkog plana naselja Novi centar, Zavod izdaje u lipnju $1971 . .^{15}$

Rasprave o izboru mjesta za lokaciju nove zgrade knjižnice vođene su kontinuirano tijekom 1970. i 1971. godine, kada je održana i javna rasprava sa zainteresiranom javnošću i stručnjacima s područja građevine i arhitekture ${ }^{16}$, o čemu je dopisom obaviješten predsjednik Skupštine Općine Karlovac prof. Rudolf Dubravčić ${ }^{17}$, a i mediji su s velikim zanimanjem popratili mišljenja i prijedloge o lokaciji nove knjižnice.

Prema prvim grubim procjenama, za izgradnju je bilo potrebno oko 3,5 milijuna dinara. Početkom 1971., na temelju preporuke Skupštine Općine Karlovac, na 23. Zajedničkoj sjednici Općinskog, Privrednog, Prosvjetno-kulturnog i Socijalno-zdravstvenog vijeća donesen je zaključak da se pasivne kamate s računa Općine Karlovac izdvajaju na poseban račun za izgradnju knjižnice. ${ }^{18}$ Istu preporuku o ustupanju pasivnih kamata za izgradnju knjižnice Skupština Općine Karlovac upućuje radnim organizacijama i ustanovama Karlovca, što su svi prihvatili. Kako bi se zatvorila financijska konstrukcija, Knjižnica je uz naknadu ustupila svoje prostore u Gundulićevoj ulici Ljubljanskoj banci, a odjeli i fond knjižnice do završetka izgradnje nove zgrade privremeno su preseljeni. ${ }^{19}$ Ostatak sredstava za gradnju osigurala je Skupština Općine Karlovac dizanjem namjenskog kredita, a računa se i na sredstva iz fondova (molbe za učešće u izgradnji upućene su

\footnotetext{
13 Arhiva Gradske knjižnice „Ivan Goran Kovačić“ Karlovac, Zapisnik sa sjednice Savjeta za biblioteke Hrvatske od 24. 11. 1970.

14 Arhiva GKIGK, Zahtjev Općinskom zavodu za komunalne poslove i urbanizam, Karlovac od 18. 12. 1970.

15 Arhiva GKIGK, Gradska biblioteka, Karlovac, podaci o uvjetima građenja. Općinski zavod za komunalne poslove i urbanizam. Br.: 20/2-2715/1971 od 17. 6. 1971.

16 Arhiva GKIGK, Zapisnik javne rasprave o lokaciji za novu zgradu Gradske biblioteke „Ivan Goran Kovačić" od 28. 4. 1971.

17 Arhiva GKIGK, Dopis Gradske biblioteke „Ivan Goran Kovačić“ od 4. 5. 1971.

18 Arhiva GKIGK, Zaključak sa 23. zajedničke sjednice Općinskog, Privrednog, Prosvjetno-kulturnog i Socijalno-zdravstvenog vijeća od 26. 1. 1971.

19 Bišćan, Frida. Nav. dj., str. 31-34.
} 
1972. na adrese Savjeta za naučni rad i Fonda za unapređenje kulturnih djelatnosti Socijalističke Republike Hrvatske). ${ }^{20}$

U lipnju 1971. dovršen je Investicioni program za izgradnju zgrade biblioteke u novom dijelu grada Karlovca. Početkom srpnja 1971. Skupština Općine Karlovac šalje poziv na uži natječaj za izradu idejnog rješenja zgrade za Gradsku biblioteku u Karlovcu na adrese četvorice arhitekata (Projektni biro AGI-46, arh. Slavko Jelinek; Milan Bijelić, Radovan Nikšić i Mladen Vodička) ${ }^{21}$, a 1. 8. 1971. putem Saveza arhitekata Hrvatske iz Zagreba raspisuje uži javni natječaj za izradu idejnog rješenja zgrade Gradske biblioteke $u$ Karlovcu. ${ }^{22}$ Poziv na natječaj sadržavao je sljedeće priloge: 1 . Rješenje o lokaciji, 2. Situacioni nacrt zemljišta u mjerilu 1:1000 (izvadak iz urbanističkog plana „Novo središte“), 3. Projektni program i 4. Uvjeti natječaja za izradu idejnog rješenja Gradske biblioteke. U sklopu zone predviđene urbanističkim planom za grad Karlovac prostorna organizacija novog društveno-kulturnog centra predviđala je sljedeće sadržaje: kino, kazalište, galeriju, arhiv, muzičku školu, administrativno-upravne objekte i gradsku knjižnicu. Projektni program predviđao je etapnu izgradnju: etapa A - I. predviđala je prostor za čitače (odjeli za odrasle i djecu, posudbeni pultovi, čitaonice); prostor za nabavu i obradu knjiga, časopisa i novina; prostor za zbirke građe posebne vrste; prostore radionica i prostore uprave; etapa B - II.: spremište za knjige, časopise i novine; prostor za nabavu i obradu knjiga, časopisa i novina; prostor za zbirke građe posebne vrste; matičnu službu i stan za nadstojnika zgrade. Nakon provedenog natječaja i na temelju prispjelih radova, zaključak ocjenjivačkog suda bio je da nijedan rad u potpunosti ne zadovoljava zadane uvjete, ali su pozvani arhitekti Bijelić i Vodička da nadopune svoja rješenja prema poslanim primjedbama. ${ }^{23} \mathrm{U}$ drugoj fazi užeg natječaja, početkom 1972. godine, odabran je projekt arhitekta Mladena Vodičke (projekt je nagrađen na Salonu arhitekture u Zagrebu 1976.). Autor je predvidio gradnju u tri etape, stan iz II. etape isključen je iz projekta, a III. etapa predvidjela je dvoranu s oko 200 sjedišta koja bi mogla služiti i kao izložbeni prostor koji se otvaranjem povezuje s vanjskim prostorom.

Skupština grada Karlovca potpisuje ugovor za izradu glavnog projekta sa Zavodom za arhitektonsku investicionu dokumentaciju Arhitektonskog fakulteta u

\footnotetext{
20 Arhiva GKIGK, Dopis: 1. Socijalistička Republika Hrvatska, Fond za unapređenje kulturnih djelatnosti, 1972., Dopis 2. Socijalistička Republika Hrvatska, Savjet za naučni rad od 28. 2. 1972.

21 Arhiva GKIGK, Skupština općine Karlovac, poziv na uži javni natječaj. Karlovac, srpanj 1971.

22 Arhiva GKIGK, Skupština općine Karlovac putem Saveza arhitekata Hrvatske raspisuje uži javni natječaj. Zagreb, 1. 8. 1971.

23 Arhiva GKIGK, Zapisnik sa sastanka Ocjenjivačkog suda natječaja za izradu idejnog rješenja Biblioteke u Karlovcu (13.-21. 12. 1971.) i Zaključci Ocjenjivačkog suda natječaja za izradu idejnog rješenja Biblioteke u Karlovcu od 22. 12. 1971.
} 
Zagrebu. Općinski zavod za komunalne poslove Općine Karlovac izdaje 6. 12. 1972. Rješenje o osnivanju komisije za provedbu postupka za prikupljanje ponuda za gradnju zgrade knjižnice, što je obavljeno u zadanom roku. Budući da prikupljena sredstva nisu bila dostatna, početak gradnje bio je odgođen i postupak je ponovljen 1974. godine, kada je za izvođača radova odbrano Građevno poduzeće „Novotehna“ iz Karlovca. ${ }^{24}$ Tijekom svih tih godina zanimanje javnosti za izgradnju nove zgrade knjižnice i dalje je bilo veliko, a o tome svjedoče brojni članci u dnevnim novinama koje su pratile razvoj prikupljanja sredstava i početka gradnje. ${ }^{25}$ Kamen temeljac položen je 1. 8. 1974. ${ }^{26}$, a tom je prilikom književnik Oto Šolc rekao: „Želim ovoj biblioteci da ima toliko knjiga koliko će zrna pijeska biti ugrađeno u ovu zgradu." Iako su završetak radova i otvorenje knjižnice bili predviđeni za Dan Republike 1975., radovi su kasnili zbog nedostatka predviđenih materijala na domaćem tržištu, pa je Arhitektonski fakultet u Zagrebu bio prisiljen mijenjati neke detalje projekta. U srpnju 1975. kao izvođač za izradu namještaja i opreme za knjižnicu izabrana je tvornica namještaja „Polet“ iz Duge Rese, s kojom je 15. rujna 1975. potpisan ugovor. ${ }^{27} \mathrm{Na}$ svečanosti 5. travnja 1976. član Savjeta federacije Ivo Vejvoda predao je na upotrebu nove zgrade Knjižnice i Galerije. Ključeve nove knjižnice preuzela je tadašnja ravnateljica Milica Radovinović. Uz pomoć učenika karlovačkih škola započela je selidba u novi prostor, a svoj doprinos dale su i radne organizacije koje su ustupile vozila za prijevoz knjiga. Knjižnica je otvorena za korisnike u svibnju 1976. Iste godine u Vjesniku bibliotekara Hrvatske, u rubrici Pregled, Milica Radovinović objavljuje tekst o otvorenju nove zgrade karlovačke knjižnice. ${ }^{28}$

Završena I. etapa zgrade bila je projektom predviđena za spremište knjiga, ali su do izgradnje preostalih etapa u taj prostor smješteni svi odjeli i službe. ${ }^{29}$ Devedesetih godina 20. stoljeća dolazi do malih izmjena, knjigovežnica je preseljena u suteren, a u taj prostor izmješten je dio zavičajne zbirke.

Od izgradnje, tijekom narednih dvadeset godina, taj je prilagođeni prostor $\mathrm{u}$ potpunosti ispunjavao sve uvjete potrebne za rad narodne knjižnice, da bi se sredinom devedesetih povećanjem knjižničnog fonda ponovno počeo javljati problem

\footnotetext{
24 Arhiva GKIGK, Zapisnik o prikupljanju ponuda od 7. 12. 1972. i 1. 4. 1974.

25 Perić, Nikola. Kako će se graditi biblioteka? // Karlovački tjednik 22, 29(1974), 12.

26 Radovinović, Milica. Polaganje kamena temeljca novoj zgradi Gradske biblioteke „Ivan Goran Kovačić" u Karlovcu // Vjesnik bibliotekara Hrvatske 20, 1/4(1974), 27-28.

27 Arhiva GKIGK, Ugovor o izvođenju za izvedbu namještaja i opreme Gradske biblioteke „Ivan Goran Kovačić“ u Karlovcu. Duga Resa, 15. rujna 1975.

28 Radovinović, Milica. Nova zgrada Gradske biblioteke „Ivan Goran Kovačićc Karlovac. // Vjesnik bibliotekara Hrvatske 22, 1/4(1976), 55-57.

29 Eleta, Nada. Gradska knjižnica od 1945. do 2007. godine. // Gradska knjižnica „Ivan Goran Kovačićc" - Karlovac : 1838.-2008. : prilozi za povjesnicu / urednica Frida Bišćan. Karlovac : Gradska knjižnica „Ivan Goran Kovačić“, 2008. Str. 83-86.
} 
nedostatka prostora. Dio periodike i knjiga privremeno je smješten u susjednom Arhivu kako bi se rasteretio prostor Knjižnice, pa dovršenje projekta arhitekta Vodičke ponovno postaje aktualno. Tijekom Domovinskog rata Knjižnica je teško oštećena, izravan pogodak u drugi kat (Studijski odjel) oštetio je dio građe, a sva su stakla na njezinoj zgradi popucala. Prostor je, koliko je to bilo moguće u ratnim uvjetima, saniran kako ne bi dolazilo do daljnjeg oštećivanja i otuđivanja fonda. Nakon rata na knjižnici su izvršeni potrebni popravci, ali nedostatak prostora za fond (oko 135000 jedinica knjižnične građe), djelatnost odjela i kulturna događanja sve se više osjeća u radu s korisnicima. Kao matična knjižnica za Karlovačku županiju, imala je i obveze ispunjavanja prostornih uvjeta sukladno Zakonu o knjižnicama, Standardima za narodne knjižnice u Republici Hrvatskoj i Pravilniku o matičnoj djelatnosti knjižnica u Republici Hrvatskoj.

\section{Završetak projekta karlovačke knjižnice iz 1972. godine}

Od 2000. godine počinje se sustavnije raditi na boljoj promociji knjižnice i upoznavanju korisnika, suradnika, gradskih vlasti i medija sa svim potencijalima kojima knjižnica raspolaže i koje može ponuditi građanima Karlovca. Brojne aktivnosti, redovito popraćene u lokalnim medijima, pridonose afirmaciji kako same knjižnice tako i knjižničarske struke u cjelini. Tijekom 2002. godine u tiskanim lokalnim medijima objavljeno je više od 300 članaka vezanih uz djelatnost i aktivnosti koje su se odvijale u knjižnici. Pripreme za proslavu 165. obljetnice Knjižnice 2003. godine usmjerene su ne samo na program proslave već i na javno zagovaranje knjižnice i njezinih usluga sa svrhom osiguravanja financijskih sredstava kojima bi se osigurao završetak projekta arhitekta Mladena Vodičke iz 1972. godine. Odjeci obilježavanja Dana Knjižnice popraćeni su člancima u Jutarnjem listu, Karlovačkom listu, Karlovačkom tjedniku i Večernjem listu, s naglaskom na brojnim događanjima i vrijednoj knjižničnoj građi, ali i nedostatku prostora za smještaj građe.$^{30}$ Redovita komunikacija s Gradom putem izvješća i osobnim kontaktima, kao i brojna medijska izvješća o izuzetnoj aktivnosti Knjižnice (preko 400 članaka u 2003. godini), donose pozitivne rezultate. U lipnju 2003. godine ravnateljica Nada Eleta šalje Gradu Karlovcu, Upravnom odjelu za komunalne djelatnosti, zamolbu za utvrđivanje javnog interesa za dogradnju knjižnice prema dostavljenoj projektnoj dokumentaciji. ${ }^{31}$ Javni interes utvrđen je zaključkom Gradskog poglavarstva Grada Karlovca ${ }^{32}$ i na temelju čl. 44 Odluke o izmjeni

30 Bičak, Snježana. Knjižnica u vrhu hrvatskog standarda. // Večernji list 47, 14187(2003), str. 43.

31 Arhiva GKIGK, Gradska knjižnica „Ivan Goran Kovačić““. Zamolba za utvrđivanje javnog interesa. Karlovac, 9. 6. 2003.

32 Arhiva GKIGK, Zaključak Gradskog poglavarstva Grada Karlovca (klasa 022-05/03-01/0014, ur. br. 2133/01-03-03-37) od 8. srpnja 2003. 
GUP-a grada Karlovca. ${ }^{33}$ Time Grad Karlovac donosi odluku o nastavku gradnje Gradske knjižnice, tj. završetku projekta započetog prije gotovo trideset godina. Osim Grada, projekt je podržalo i Ministarstvo kulture obećavši sufinanciranje izgradnje, pa slijedi obiman posao stvaranja kontakata i prikupljanja sve potrebne dokumentacije. ${ }^{34} \mathrm{U}$ dogovoru s vlasnikom projekta, Arhitektonskim fakultetom iz Zagreba, dogovaraju se manje izmjene projekta arhitekta Vodičke. U proteklih trideset godina društveni i tehnološki razvitak utjecao je i na razvoj knjižničarske struke, pa je bilo potrebno uskladiti prvobitni projekt i prostor s novim potrebama suvremene knjižnice. Prostor je trebalo prilagoditi potrebama korisnika 21. stoljeća i novim informacijskim tehnologijama. Na idejnom rješenju rade dr. sc. Boris Morsan i dr. sc. Dražen Juračić, koji se ubrzo zbog brojnih drugih obveza povlači iz projekta, a na izradi projekta pridružuje se dipl. arhitekt Relja Šurbat.

Iako je početak dogradnje bio predviđen za 2004. godinu, licencirana tvrtka za kontrolu projekta uočila je nedostatke, pa je Grad Karlovac tražio doradu arhitektonskog i provedbenog, kao i glavnog izvedbenog projekta. Nakon izvršenih izmjena i dorada projekta, ravnateljica Knjižnice 29. travnja 2005. podnosi Zahtjev za izdavanje lokacijske dozvole, a 12. svibnja 2005. ponavlja zamolbu za utvrđivanje javnog interesa. Grad Karlovac, UO za prostorno planiranje i upravljanje imovinom, 21. srpnja 2005. daje suglasnost za ishođenje lokacijske dozvole za dogradnju i adaptaciju Gradske knjižnice u skladu s arhitektonskim projektom tvrtke „Girus“ d.o.o. iz Zagreba. ${ }^{35}$ Lokacijska dozvola izdana je 5. rujna 2005., ${ }^{36}$ a građevinska dozvola 1. prosinca 2005. prema glavnom projektu oznake I.G.K. 0109/2005. ${ }^{37}$

S obzirom na to da je Grad vlasnik zemljišta, Gradsko vijeće na 3. sjednici održanoj 20. listopada 2005. donosi odluku o besplatnom prijenosu prava vlasništva GK IGK na nekretnini oznake k.č.br. 1519/I k.o. Karlovac II, od-

\footnotetext{
33 Odluka o izmjeni i dopuni GUP-a Grada Karlovca. // Glasnik Grada Karlovca 32, 7(1995), 119 i Odluka o izmjenama i dopunama GUP-a Grada Karlovca. // Glasnik Grada Karlovca 39, 1(2002), str. 42.

34 Badovinac, Robert. Uskoro nastavak izgradnje zgrade knjižnice? // Karlovački tjednik 50, 17(2003), str. 13.

35 Arhiva GKIGK, Grad Karlovac, UO za prostorno planiranje i upravljanje imovinom. Suglasnost za ishođenje lokacijske dozvole za dogradnju i adaptaciju Gradske knjižnice, 21. srpnja 2005.

36 Arhiva GKIGK, Ured državne uprave u Karlovačkoj županiji, Služba za prostorno uređenje, zaštitu okoliša, graditeljstvo i imovinsko-pravne odnose - Odsjek za prostorno uređenje, zaštitu okoliša i graditeljstvo. Lokacijska dozvola od 5. rujna 2005.

37 Arhiva GKIGK, Ured državne uprave u Karlovačkoj županiji, Služba za prostorno uređenje, zaštitu okoliša, graditeljstvo i imovinsko-pravne odnose - Odsjek za prostorno uređenje, zaštitu okoliša i graditeljstvo. Građevinska dozvola. Karlovac, 1. 12. 2005.
} 
nosno prema gruntovnim podacima k.č.br. 1309/I, k.o. Karlovac. ${ }^{38}$ Ugovor o darovanju nekretnine između Grada Karlovca i Gradske knjižnice „Ivan Goran Kovačić" sklopljen je 26. siječnja 2006. ${ }^{39} \mathrm{Na}$ temelju Ugovora Općinski sud u Karlovcu donosi Rješenje o uknjižbi prava vlasništva na Gradsku knjižnicu „Ivan Goran Kovačić““.40

Gradsko poglavarstvo imenuje Povjerenstvo za provođenje postupka nabave za odabir izvoditelja radova za nastavak izgradnje Gradske knjižnice. Nakon provedenog natječaja, koji dobiva tvrtka „Kolos“ iz Duga Rese, Knjižnica dobiva suglasnost za zaključenje Ugovora o građenju koji u ime investitora potpisuje gradonačelnik Karlovca Miro Škrgatić, dipl. ing. arh. ${ }^{41}$ Knjižnica 1. kolovoza 2006. Državnom inspektoratu i Inspekciji rada prijavljuje početak radova na građevini: Rekonstrukcija i dogradnja Gradske knjižnice „Ivan Goran Kovačić“ u Karlovcu na adresi Lj. Šestića 1 . Kamen temeljac položen je uoči Dana domovinske zahvalnosti 4. kolovoza 2006. godine. ${ }^{42}$ Prva faza izgradnje, građevinski radovi, završena je u prosincu iste godine. Od srpnja do prosinca 2006. tiskani su mediji nizom od dvadeset članaka popratili početak i tijek radova na dogradnji Gradske knjižnice.

U siječnju 2007., prilikom radnog posjeta Karlovačkoj županiji, novoizgrađeni objekt posjetio je ministar kulture mr. sc. Božo Biškupić. ${ }^{43}$ Obećao je financijsku potporu Ministarstva kulture i za 2007. godinu te dogovorio s gradonačelnikom Karlovca da se sredstva predviđena za dogradnju karlovačke knjižnice povećaju s ciljem završetka radova do jeseni, kako bi proslava otvorenja Mjeseca hrvatske knjige 2007. bila održana u novim prostorima karlovačke knjižnice. Nakon što je Knjižnica dobila suglasnost Grada za drugu fazu dogradnje, započinje projektiranje interijera i opreme, a početkom ožujka raspisan je natječaj za nastavak radova. U travnju 2007. potpisan je ugovor s tvrtkom „Kolos“ iz Duge Rese za izvođenje građevinskih radova na unutrašnjem uređenju i uređenju okoliša. Nakon toga slijede natječaji za nabavu namještaja i komunikacijsko-informacijske opreme (namještaj dobavljaju Primat RD d.o.o. i Stolarija „Lipošćak“, a računalnu opremu tvrtka Open IT). Ubrzano se radi na završavanju radova unutrašnjeg uređenja, opremanja namještajem i instaliranjem IT opreme kako bi sve bilo završeno do

\footnotetext{
38 Arhiva GKIGK, Grad Karlovac. Gradsko vijeće. Odluka o prijenosu prava vlasništva od 20. listopada 2005.

39 Arhiva GKIGK, Ugovor o darovanju nekretnine. Karlovac, 26. siječnja 2006.

40 Arhiva GKIGK, RH-Općinski sud u Karlovcu. Rješenje o uknjižbi vlasništva. Karlovac, 13. veljače 2006.

${ }^{41}$ Pulez, Željka. Kreće dogradnja karlovačke Gradske knjižnice. // Karlovački list 11, 3416(2006), 3.

42 Kundić, Damir. Veliki dan za karlovačku kulturu. // Novi list 59, 18999(2006), 12.

43 Magličić-Zinaja, Ida. Za Karlovačku županiju više novca. // Večernji list 48, 15506(2007), 18.
} 
listopada 2007., za kada je predviđeno otvaranje. ${ }^{44}$ Nakon završetka radova na unutrašnjem uređenju Knjižnica je bila zatvorena za korisnike od 19. rujna do 15. listopada 2007. zbog preseljenja fonda u novi prostor i kontrole prostora od strane nadležnih službi. Nakon dobivanja Uporabne dozvole ${ }^{45}$, svečano otvorenje dograđenog dijela knjižnice održano je povodom nacionalne manifestacije Mjeseca hrvatske knjige 15 listopada 2007. godine. Knjižnicu je otvorio ministar kulture mr. sc. Božo Biškupić, a nazočio je i ministar Branko Vukelić, uz prisutnost mnogih uglednih kulturnih i javnih djelatnika i knjižničara iz cijele Hrvatske. ${ }^{46}$

Svijest javnosti i medija o važnosti projekta karlovačke knjižnice za lokalnu zajednicu i cijelu kulturnu javnost, kao i njihov interes za dogradnju, bio je velik. To dokazuju brojne pozitivno intonirane objave u medijima. U razdoblju od siječnja do listopada 2007. godine objavljena su 22 članka u tiskanim medijima, a samo otvorenje Knjižnice popratilo je tridesetak medijskih objava u novinama (8), na radiju (4) i televiziji (3) te na različitim portalima (Ministarstvo kulture, knjižnice, agencije, HKD i sl.).

Dograđeni dio knjižnice ima brutopovršinu od $2000 \mathrm{~m}^{2}\left(1738 \mathrm{~m}^{2}\right.$ neto $)$ na dvije etaže. U prizemlju se nalazi Informativno-posudbeni odjel, višenamjenska dvorana (koja od 1. ožujka 2009. nosi naziv Ilirska dvorana), kafić, kancelarija za Bibliobusnu službu, spremište i garaža za bibliobus. Na katu su Odjel za djecu i mladež, Igraonica za djecu predškolskog uzrasta s pozornicom i Glazbeni odjel. Novi je dio, u skladu sa starim, modernog arhitektonskog oblika i vedrih boja, a stari i novi dio kvalitetno su povezani u jedinstven prostor. Glavni ulaz nalazi se na južnoj strani i gleda na travnatu površinu koja vizualno „ulazi“ u knjižnicu zelenim podom koji teče kroz prostor prizemlja. Suvremeno dizajniran namještaj (police i stolovi) izrađen je u drvetu (svijetla bukovina) čija toplina dodatno oplemenjuje prostor. Živost Dječjem odjelu i Igraonici daju stolovi u vedrim bojama (crvena i žuta), kao i živopisne police u dijelu prostora za predškolce u obliku jagode i kruške.

I tako je nakon više od trideset godina završena izgradnja prve namjenski projektirane narodne knjižnice u Hrvatskoj na čijem su ostvarenju radile generacije vrijednih knjižničara predvođene ravnateljima vizionarima, knjižničarima koji su živjeli svoju struku.

\footnotetext{
${ }_{44}$ Rataić-Vojak, Božica. Vodičekov projekt napokon postao stvarnost. // Karlovački tjednik 54, 36(2007), str. 15.

45 Arhiva GKIGK, Ured državne uprave u Karlovačkoj županiji, Služba za prostorno uređenje, zaštitu okoliša, graditeljstvo i imovinsko-pravne odnose - Odsjek za prostorno uređenje, zaštitu okoliša i graditeljstvo. Uporabna dozvola. Karlovac, 28. 9. 2007.

46 Ministar Biškupić otvorio Gradsku knjižnicu i Mjesec hrvatske knjige. [citirano: 2016-0217]. Dostupno na http://www.min-kulture.hr/default.aspx?id=3374.
} 


\section{Zaključak}

Prva namjenski građena narodna knjižnica zaživjela je u punom sjaju završenog projekta nakon više od trideset godina. Time su ostvareni uvjeti za djelovanje knjižnice u 21. stoljeću, knjižnice koja osigurava prostor za sve aspekte knjižničnog poslovanja: fond, njegovu stručnu obradu te potpunu dostupnost fonda $\mathrm{i}$ prostora korisniku uz suvremenu informacijsku tehnologiju. Uslijedila je ideja da prostor bude prilagođen funkciji suvremene knjižnice kao mjesta susreta i cjeloživotnog učenja koji omogućuje društveni i profesionalni razvoj kako korisnicima tako i osoblju knjižnice.

Kao što je već istaknuto u uvodu, bitni preduvjeti za izgradnju ili adaptaciju knjižnične zgrade jesu jasno definirani ciljevi, počevši od suradnje unutar knjižnice, ali i između knjižnice i osnivača, odnosno projektanta. Pri planiranju treba uzeti u obzir potrebe knjižnice i lokalne zajednice oslanjajući se na potrebe suvremenog društva i razvoja struke u budućnosti. Aktivna i konstruktivna suradnja s projektantima te sudjelovanje u svakoj fazi projektiranja i kasnije izgradnje zasigurno su utjecali na smanjivanje mogućih pogrešaka u konačnom izgledu i funkcionalnosti prostora.

Dizajn prostora i vizualna prepoznatljivost važan su segment uređenja. Posljednjih godina sve više knjižnica u opremanju svojih prostora koristi prirodne materijale (drvo za izradu namještaja, a za podove drvo/parket, kamen i PVC-mase). U tom stilu opremljena je i karlovačka knjižnica. Drveni namještaj daje prostoru toplinu, uz dodatnu vedrinu toplih boja podova i namještaja. Otvorenost prostora korisnicima, funkcionalnost opreme i jednostavnost grafičkog dizajna pridonose osnovnoj funkciji knjižnice kao mjesta susreta za sve kategorije korisnika, a njezini fondovi i raznoliki programi pružaju mogućnost za korisno provedeno slobodno vrijeme u kojem svatko može pronaći nešto za sebe.

Za uspješan rad i razvoj potrebna je stalna komunikacija između knjižnice i lokalne zajednice. Odnosima s javnošću knjižnica se predstavlja zajednici i senzibilizira ju dajući infomacije o svojim službama i uslugama. To ostvaruje kvalitetnom suradnjom s medijima, osnivačima i ostalima koji odlučuju, u zakonodavnom ili financijskom smislu, o razvoju knjižnice.

\section{IZVORI I LITERATURA}

Izvori, Arhiva Gradske knjižnice „Ivan Goran Kovačić“ Karlovac (Arhiva GKIGK)

Dopis Gradske biblioteke „Ivan Goran Kovačić“” od 4. 5. 1971.

Dopis Socijalistička Republika Hrvatska, Fond za unapređenje kulturnih djelatnosti, Karlovac, 1972. 
Dopis Socijalistička Republika Hrvatska, Savjet za naučni rad od 28. 2. 1972.

Grad Karlovac, UO za prostorno planiranje i upravljanje imovinom. Suglasnost za ishođenje lokacijske dozvole za dogradnju i adaptaciju Gradske knjižnice, 21. srpnja 2005.

Grad Karlovac. Gradsko vijeće. Odluka o prijenosu prava vlasništva od 20. listopada 2005.

Gradska biblioteka, Karlovac, podaci o uvjetima građenja. Općinski zavod za komunalne poslove i urbanizam. Br.: 20/2-2715/1971 od 17. 6. 1971.

Gradska knjižnica „Ivan Goran Kovačić“. Zamolba za utvrđivanje javnog interesa. Karlovac, 9. 6. 2003.

O osnovnim načelima izrade projektnog rješenja za gradnju nove biblioteke. Karlovac, 1971.

Poziv na uži natječaj za izradu idejnog rješenja zgrade za Gradsku biblioteku u Karlovcu. Skupština općine Karlovac, srpanj 1971.

RH-Općinski sud u Karlovcu. Rješenje o uknjižbi vlasništva. Karlovac, 13. veljače 2006.

Skupština općine Karlovac putem Saveza arhitekata Hrvatske. Poziv na uži javni natječaj za izradu idejnog rješenja zgrade Gradske biblioteke u Karlovcu. Zagreb, 1. 8. 1971.

Ugovor o darovanju nekretnine. Karlovac, 26. siječnja 2006.

Ugovor o izvođenju za izvedbu namještaja i opreme Gradske biblioteke „Ivan Goran Kovačićc“ u Karlovcu. Duga Resa, 15. rujna 1975.

Ured državne uprave u Karlovačkoj županiji, Služba za prostorno uređenje, zaštitu okoliša, graditeljstvo i imovinsko-pravne odnose - Odsjek za prostorno uređenje, zaštitu okoliša i graditeljstvo. Lokacijska dozvola od 5. rujna 2005.

Ured državne uprave u Karlovačkoj županiji, Služba za prostorno uređenje, zaštitu okoliša, graditeljstvo i imovinsko-pravne odnose - Odsjek za prostorno uređenje, zaštitu okoliša i graditeljstvo. Građevinska dozvola. Karlovac, 1. 12. 2005.

Ured državne uprave u Karlovačkoj županiji, Služba za prostorno uređenje, zaštitu okoliša, graditeljstvo i imovinsko-pravne odnose - Odsjek za prostorno uređenje, zaštitu okoliša i graditeljstvo. Uporabna dozvola. Karlovac, 28. 9. 2007.

Zahtjev Općinskom zavodu za komunalne poslove i urbanizam, Karlovac od 18. 12. 1970.

Zaključak sa 23. zajedničke sjednice Općinskog, Privrednog, Prosvjetno-kulturnog i Socijalno-zdravstvenog vijeća od 26. 1. 1971.

Zaključak Gradskog poglavarstva Grada Karlovca (klasa 022-05/03-01/0014, ur. br. 2133/01-03-03-37) od 8. srpnja 2003. 
Zaključci Ocjenjivačkog suda natječaja za izradu idejnog rješenja Biblioteke u Karlovcu od 22. 12. 1971.

Zapisnik sa sjednice Savjeta za biblioteke Hrvatske od 24. 11. 1970.

Zapisnik javne rasprave o lokaciji za novu zgradu Gradske biblioteke "Ivan Goran Kovačić" od 28. 4. 1971.

Zapisnik sa sastanka Ocjenjivačkog suda natječaja za izradu idejnog rješenja Biblioteke u Karlovcu (13.-21. 12. 1971.).

Zapisnik o prikupljanju ponuda od 7. 12. 1972. i 1. 4. 1974.

\section{LITERATURA}

Badovinac, Robert. Uskoro nastavak izgradnje zgrade knjižnice? // Karlovački tjednik 50, 17(2003), 13.

Bičak, Snježana. Knjižnica u vrhu hrvatskog standarda. // Večernji list 47, 14187(2003), 43.

Bišćan, Frida. Karlovačka knjižnica - nova vizura grada. // Narodne knjižnice za sadašnjost i budućnost: koncepti, arhitektura, tehnologija : zbornik radova / 5. savjetovanje za narodne knjižnice u Republici Hrvatskoj, Lovran, 3.-6. listopada 2007. ; [urednica Ljiljana Črnjar ; prijevodi tekstova sa slovenskog i engleskog Andreja Silić Švonja]. Str. 31-34.

Eleta, Nada. Gradska knjižnica od 1945. do 2007. godine. // Gradska knjižnica „Ivan Goran Kovačić“" - Karlovac : 1838.-2008. : prilozi za povjesnicu / urednica Frida Bišćan. Karlovac : Gradska knjižnica „Ivan Goran Kovačić“, 2008. Str. 83-86.

Faulkner-Brown, Harry. Some thoughts on the design of major library buildings. // Intelligent Library Buildings : Proceedings of the 10th Seminar of IFLA's Library Buildings and Equipment Section. The Hague, Netherlands, 1997. Str. 14-26. [citirano: 2017-04-20 ]. Dostupno na https:/www.ifla.org/publications/intelligent-library-buildings

Glodić, Bogdan. Nova kuća za čitaoce. // Karlovački tjednik 18, 47/48(1970), 16.

IFLA-ine smjernice za narodne knjižnice / uredile Christie Koontz i Barbara Gubbin ; [s engleskog prevela Irena Kranjec]. 2. hrvatsko izd. (prema 2. izmijenjenom izd. izvornika). Zagreb : Hrvatsko knjižničarsko društvo, 2011.

IFLA Library building guidelines : developments and reflections. Muenchen, K. G. Saur, 2007. Str. 13-26.

Key Issues in Building Design / authors Anders C. Dahlgren ... [et al.]. IFLA Library Buildings and Equipment Section 2009. [citirano: 2016-02-17]. Dostupno na http://www.ifla.org/files/assets/library-buildings-and-equipment/Publications/ key-issues-in-building-design-en.pdf

Kundić, Damir. Veliki dan za karlovačku kulturu. // Novi list 59, 18999(2006), 12. 
Magličić-Zinaja, Ida. Za Karlovačku županiju više novca. // Večernji list 48, 15506(2007), 18.

Mikulić, Rosana. Ilirskoga čitanja društvo / Društvo narodne čitaonice. // Gradska knjižnica „Ivan Goran Kovačić“ - Karlovac : 1838.-2008. : prilozi za povjesnicu / urednica Frida Bišćan. Karlovac : Gradska knjižnica „Ivan Goran Kovačić“, 2008. Str. 36.

Ministar Biškupić otvorio Gradsku knjižnicu i Mjesec hrvatske knjige. [citirano: 201602-17]. Dostupno na http://www.min-kulture.hr/default.aspx?id=3374

Novljan, Silva. Načrtovanje prostora za knjižnično dejavnost v lokalni skupnosti. // Načrtovanje gradnje in opreme knjižnic / Silva Novljan, Robert Potokar, Rajko Slokar. Ljubljana : Narodna in univerzitetna knjižnica, 2001. Str. 57-70.

Odluka o izmjeni i dopuni GUP-a Grada Karlovca. // Glasnik Grada Karlovca 32, 7(1995), 119.

Odluka o izmjenama i dopunama GUP-a Grada Karlovca. // Glasnik Grada Karlovca 39, 1(2002), 42.

Perić, Nikola. Kako će se graditi biblioteka? // Karlovački tjednik 22, 29(1974), 12.

Pulez, Željka. Kreće dogradnja karlovačke Gradske knjižnice. // Karlovački list 11, 3416(2006), 3.

Radovinović, Milica. Polaganje kamena temeljca novoj zgradi Gradske biblioteke „Ivan Goran Kovačićc u Karlovcu // Vjesnik bibliotekara Hrvatske 20, 1/4(1974), 27-28.

Radovinović, Milica. Nova zgrada Gradske biblioteke „Ivan Goran Kovačić“ Karlovac. // Vjesnik bibliotekara Hrvatske 22, 1/4(1976), 55-57.

Rataić-Vojak, Božica. Vodičekov projekt napokon postao stvarnost. // Karlovački tjednik 54, 36(2007), 15.

Rojnić, Matko. Gradska biblioteka "Ivan Goran Kovačić” u Karlovcu : građevni program. Zagreb, 1970.

Stipanov, Josip. Matko Rojnić - pokretač i obnovitelj hrvatskog knjižničarstva. // Stručni skup Matko Rojnić : knjižničar i povjesničar povodom 100. obljetnice rođenja (1908.-1981.), Medulin, 12. svibnja 2008. : zbornik radova / uredili Bruno Dobrić i Slavko Harni. Zagreb : Hrvatsko knjižničarsko društvo : Nacionalna i sveučilišna knjižnica ; Pula : Gradska knjižnica i čitaonica, 2010. Str. 22-41.

Vodička, Mladen. Gradska biblioteka „Ivan Goran Kovačić” u Karlovcu. // Čovjek i prostor 24, 290(1977), 4-7. 